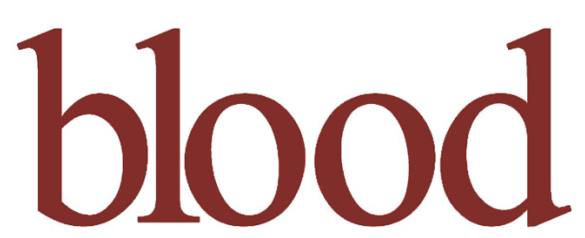

Prepublished online September 6, 2013;

doi:10.1182/blood-2013-04-499335

\title{
Protein S levels and the risk of venous thrombosis: results from the MEGA case-control study
}

Maria Carolina Pintao, Daniel D. Ribeiro, Irene D. Bezemer, Andrea A. Garcia, Marieke C.H. de Visser, Carine J.M. Doggen, Willem M. Lijfering, Pieter H. Reitsma and Frits R. Rosendaal

Information about reproducing this article in parts or in its entirety may be found online at:

http://bloodjournal.hematologylibrary.org/site/misc/rights.xhtml\#repub_requests

Information about ordering reprints may be found online at:

http://bloodjournal.hematologylibrary.org/site/misc/rights.xhtml\#reprints

Information about subscriptions and ASH membership may be found online at:

http://bloodjournal.hematologylibrary.org/site/subscriptions/index.xhtml

Advance online articles have been peer reviewed and accepted for publication but have not yet appeared in the paper journal (edited, typeset versions may be posted when available prior to final publication). Advance online articles are citable and establish publication priority; they are indexed by PubMed from initial publication. Citations to Advance online articles must include the digital object identifier (DOls) and date of initial publication.

Blood (print ISSN 0006-4971, online ISSN 1528-0020), is published weekly by the American Society of Hematology, 2021 L St, NW, Suite 900, Washington DC 20036.

Copyright 2011 by The American Society of Hematology; all rights reserved.

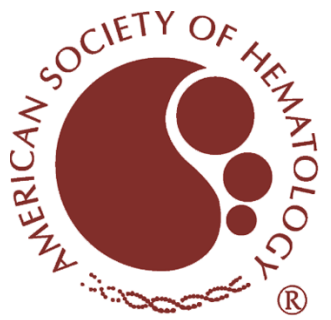




\section{Protein S levels and the risk of venous thrombosis: results from the MEGA case- control study}

Running title: Protein S levels and the risk of venous thrombosis

Maria Carolina Pintao ${ }^{1,2}$, Daniel D. Ribeiro ${ }^{3,4}$, Irene D. Bezemer ${ }^{3}$, Andrea A. Garcia ${ }^{1,2}$, Marieke C.H. de Visser ${ }^{1,2}$, Carine J.M. Doggen ${ }^{3,5}$, Willem M. Lijfering ${ }^{1,3}$, Pieter H. Reitsma $^{1,2,5}$, Frits R. Rosendaal ${ }^{1,2,3}$

${ }^{1}$ Einthoven Laboratory for Experimental Vascular Medicine, Leiden University Medical Center, Leiden, the Netherlands

${ }^{2}$ Department of Thrombosis and Haemostasis, Leiden University Medical Center, Leiden, the Netherlands

${ }^{3}$ Department of Clinical Epidemiology, Leiden University Medical Center, Leiden, the Netherlands

${ }^{4}$ Hematology, University Hospital, Universidade Federal de Minas Gerais, Belo Horizonte, Brazil

${ }^{5}$ Department of Health Technology \& Services Research, MIRA institute for Biomedical Technology and Technical Medicine, University of Twente, Enschede, the Netherlands

\section{Corresponding author:}

Prof. Dr Pieter H. Reitsma

Einthoven Laboratory for Experimental Vascular Medicine, C2-143

Leiden University Medical Center

P.O. Box 9600

2300 RC Leiden

The Netherlands

Email: p.h.reitsma@lumc.nl

Tel: +31 (0)71526 6985 / FAX: +31 (0)71 5266755 


\section{KEY POINTS}

1. Low free protein $S$ and low total protein $S$ levels could not identify subjects at risk for venous thrombosis in a population-based study.

2. Protein $S$ testing and subsequent testing on PROS1 mutations should not be considered in unselected patients with venous thrombosis. 


\section{ABSTRACT}

In thrombophilic families, protein S deficiency is clearly associated with venous thrombosis. We aimed to determine whether the same holds true in a population-based case-control study $(n=5317)$. Subjects were regarded protein $S$ deficient when protein $S$ levels were $<2.5^{\text {th }}$ percentile of the controls. Free- and total protein S deficiency was not associated with venous thrombosis: free protein $\mathrm{S}<53 \mathrm{U} / \mathrm{dL}$, odds ratio [OR] $0.82(95 \% \mathrm{Cl}, 0.56-1.21)$ and total protein $\mathrm{S}<68 \mathrm{U} / \mathrm{dL}$, OR $0.90(95 \% \mathrm{Cl}, 0.62-1.31)$. When lower cut-off values were applied, it appeared that subjects at risk of venous thrombosis could be identified at levels $<0.10^{\text {th }}$ percentile of free protein $\mathrm{S}(<33 \mathrm{U} / \mathrm{dL}$, OR $5.4 ; 95 \% \mathrm{Cl}, 0.61-48.8)$. In contrast, even extremely low total protein S levels were not associated with venous thrombosis. PROS1 was sequenced in 48 subjects with free protein $S$ level $<1^{\text {st }}$ percentile $(<46 \mathrm{U} / \mathrm{dL})$, and copy number variations were investigated in 2718 subjects, including all subjects with protein $\mathrm{S}$ (free or total) $<2.5^{\text {th }}$ percentile. Mutations in PROS1 were detected in five patients and five controls reinforcing the observation that inherited protein $\mathrm{S}$ deficiency is rare in the general population. Protein S testing and PROS1 testing should not be considered in unselected patients with venous thrombosis. 


\section{INTRODUCTION}

Protein S is a vitamin K-dependent glycoprotein that is synthesized in hepatocytes and endothelial cells. ${ }^{1}$ Protein S circulates at a concentration of $\sim 350 \mathrm{nM}$, of which $40 \%$ is free and $60 \%$ is bound to $\mathrm{C} 4 \mathrm{~b}$-binding protein. ${ }^{2}$ Protein $\mathrm{S}$ assists in the down-regulation of thrombin formation by stimulating the activity of both activated protein $\mathrm{C}$ and tissue factor pathway inhibitor. ${ }^{3,4}$

Hereditary protein $\mathrm{S}$ deficiency is a haploinsufficiency disorder associated with an increased risk of venous thrombosis. ${ }^{5}$ Protein $\mathrm{S}$ deficiency can be classified as type I (decreased levels of both total and free protein S antigen), type II (decreased APC-cofactor activity but total and free protein $S$ antigen levels within their normal ranges), and type III (decreased levels of free protein S antigen levels only). ${ }^{6}$ The genetic basis of protein $S$ deficiency is heterogeneous. More than 200 mutations in PROS1 have been described, the vast majority missense or nonsense mutations. ${ }^{7-9}$ Sequencing exons and splicing junctions of PROS1 has been successful in the identification of a mutation in only around $50 \%$ of families with protein S deficiency. ${ }^{8} \mathrm{We}$ and others have shown that gross deletions and insertions of PROS1 are present in around $30 \%$ of the point mutation-negative families. ${ }^{5,10,11}$

Most of the insights regarding the association between protein S deficiency and venous thrombosis have been derived from studies of thrombophilic families. This has led to the notion that the risk of venous thrombosis in protein $S$ deficient subjects is five to ten times higher than in non-protein $S$ deficient relatives..$^{5,12-14}$ The clinical relevance for the individual patient is substantial as subjects with familial protein $S$ deficiency have a first venous thrombosis incidence of $0.7 \%$ per year ${ }^{15}$ and an annual recurrence risk of $6-10 \% .{ }^{14,16,17}$ It is not clear whether the conclusions from these family studies can be extrapolated to the general population. The co-inheritance of other defects may contribute to or explain the risks in families, as was shown for factor V Leiden, and protein C deficiency. ${ }^{18,19}$ Relatively small 
population-based studies (maximum number of participants 327$)^{19}$ point towards a lower risk of thrombosis associated with protein S deficiency. Some studies reported up to 2.5 times increased risks, others found no increase at all. ${ }^{19-21}$

We set out to determine in a large population-based case-control study whether low levels of free or total protein S were associated with an increased risk of venous thrombosis. The molecular basis for protein $\mathrm{S}$ deficiency was also investigated by analysis of copy number variation of $P R O S 1$ and resequencing of subjects with the lowest levels of protein $S$ to support the risk estimates based on plasma levels. 


\section{METHODS}

\section{Subjects}

The MEGA case-control study has been described previously. ${ }^{22}$ Consecutive patients aged 18 to 70 years with a first episode of deep venous thrombosis or pulmonary embolism between March 1, 1999 and August 31, 2004 were included, to a total of 4956. Age- and sexmatched controls were partners of patients $(n=3297)$ or recruited by random digit dialing (RDD) between January 1, 2002 and December 1, 2004 ( $n=3000)$. The participants filled in a questionnaire on potential risk factors for venous thrombosis. Blood sampling was performed for participants included up to June 2002.

All subjects provided informed consent in accordance with the Declaration of Helsinki. The study was approved by the Medical Ethics Committee of the Leiden University Medical Center.

\section{Blood samples}

Patients diagnosed before June 1, 2002 were invited, together with their partners, for a blood sample at least three months after discontinuation of the oral anticoagulant therapy. In patients who continued to take oral anticoagulant therapy for more than one year after the event, blood was drawn during therapy. Blood was collected into tubes containing trisodium citrate $0.106 \mathrm{~mol} / \mathrm{L}$ as previously described. ${ }^{22}$ An additional control group was recruited from the population by RDD. DNA was obtained by standard methods and was available for 4485 patients and 4889 control subjects.

Total and free protein S were measured on a STA-R automated coagulation analyzer (Diagnostica Stago, Asnières, France). Total protein S was measured by an enzyme-linked immunosorbent assay, and free protein $\mathrm{S}$ was measured by an immune-turbidimetric method (both from Diagnostica Stago, Asnières, France). 


\section{Cut off points}

The range from 2.5th-97.5th percentile of both total and free protein $S$ in control subjects were considered as reference values. We also categorized cut off points into different percentiles (i.e. 97.5-75th percentile as reference group compared with the 50th-75th percentile, 50th25th percentile, 10th-25th percentile and $<10$ th percentile of the control population), to see if this would change the results. Furthermore, a sensitivity analysis was performed in which very low protein $S$ levels (i.e. $<0.5$ th percentile) were compared with the 2.5 th-97.5th percentile of (free) protein S. We did not include the 97.5-100th percentile in the reference population as

other studies suggest that high levels protein S may be indicative of underlying comorbidity. ${ }^{40}$

We also constructed cumulative distribution functions to visualize protein S levels in patients and controls. We excluded patients and controls who used vitamin $\mathrm{K}$ antagonists at blood draw, were pregnant or used oral contraceptives and made a distinction between men, women, and between patients that had provoked or unprovoked venous thrombosis.

\section{Genetic analysis of PROS1}

Copy number variations were analyzed by multiplex ligation-dependent probe amplification $(\mathrm{MLPA})^{23}$ using the SALSA MLPA KIT P112 PROS1 (MRC-Holland, Amsterdam, the Netherlands) as previously described. ${ }^{11}$

Exons and their flanking regions, and the 5'- and 3'-UT regions were resequenced using primers designed to avoid the amplification of $P R O S P$. After amplification, PCR products were sequenced using an ABI Prism ${ }^{\circledR} 3730$ DNA Analyzer (Applied Biosystems, Carlsbad, California, USA). Primers and PCR conditions are available on request. 


\section{Statistical analysis}

With linear regression methods we estimated the effect of vitamin $\mathrm{K}$ antagonist use, estrogen use, pregnancy and puerperium on protein S levels. Based on previously reported associations,$^{24}$ we also estimated the effect of obesity on protein $\mathrm{S}$ levels. Mean differences were adjusted for age and sex, as both age and sex influence protein S levels, ${ }^{25}$ and for each other in a multivariate analysis. Because there is no reason to assume that low levels of protein $\mathrm{S}$ are more common among partners of patients than in the general population, both RDD subjects and partners of patients were considered as control subjects and all analyses were unmatched.

Since protein S levels were collected after venous thrombosis, it is conceivable that the event itself influenced protein S levels. To analyze this possibility we performed a sensitivity analysis: scatter diagrams were constructed with regression lines, wherein protein S level was plotted against time between venous thrombosis and blood sampling (in patients not on vitamin $\mathrm{K}$ antagonists).

Odds ratios with $95 \%$ confidence intervals (Cls) were calculated, and were adjusted for age and sex by logistic regression methods. Since in the MEGA study cases were patients with a first venous thrombosis who were sampled from a stable, dynamic population, and since partner controls were matched on time to cases and since random controls were selected from the same population as the cases, these odds ratios can be interpreted as relative risks. ${ }^{26}$ Subjects who used vitamin $\mathrm{K}$ antagonists at the time of the blood draw were excluded when obtaining relative risk estimates. A preplanned sensitivity analysis was performed in which we excluded estrogen users and pregnant women at the time of the blood draw (as estrogen use and pregnancy decrease protein $\mathrm{S}$ levels). ${ }^{27,28}$ To further diminish the influence of estrogen related hormones to protein S levels, we restricted an analysis to men only. In addition, we assessed the risk of free and total protein S deficiency in individuals with 
a positive family history. ${ }^{44}$ Stratified analyses were performed in which the common thrombophilias (i.e. blood group non-O, factor V Leiden and prothrombin G20210A) were compared with normal and low (free) protein S levels. By doing so, one can identify possible interaction or confounding of low free and total protein S levels to the risk of venous thrombosis by the common thrombophilias.

All statistical analyses were performed with SPSS for Windows, release 20.0 (SPSS Inc, Chicago, III). 


\section{RESULTS}

\section{General characteristics}

Approximately $50 \%$ of patients and controls who were included in MEGA were tested for free and total protein S levels. No differences in clinical characteristics between tested participants and non-tested participants were observed, indicating that the tested individuals were representative of the whole of MEGA (Table 1). Of note, only 2331 patients were tested for free protein S while 2377 patients were tested for total protein S. Of controls, 2872 were tested for free protein $S$ ( $n=1479$ partners and $n=1393$ RDD controls) and 2940 for total protein $S$ ( $n=1481$ partners and $n=1459$ controls). That some patients or controls were tested for total protein $S$ only and not for free protein $S$ was due to laboratory failures. Both total and free protein $\mathrm{S}$ levels were reduced in vitamin $\mathrm{K}$ antagonist users, in pregnant women, and in women using estrogens (Table 42). Protein S levels were higher in overweight/obese control subjects than in those with normal weight.

\section{Risk estimates}

Subjects with low free protein $\mathrm{S}$ levels $\left(<2.5^{\text {th }}\right.$ percentile, $\left.53 \mathrm{U} / \mathrm{dl}\right)$ or low total protein $\mathrm{S}$ levels $\left(<2.5^{\text {th }}\right.$ percentile, $\left.<68 \mathrm{U} / \mathrm{dl}\right)$ were not at increased risk of thrombosis when compared with subjects with levels in the $2.5^{\text {th }}-97.5^{\text {th }}$ percentile; odds ratio $0.82(95 \% \mathrm{Cl}, 0.56-1.21)$ and 0.92 $(95 \% \mathrm{Cl}, 0.63-1.33)$, respectively. Estrogen use, pregnancy or puerperium may transiently decrease protein $\mathrm{S}$ levels and have influenced these findings. We therefore repeated the analysis after excluding all women who used estrogens, were pregnant or in puerperium at time of venous thrombosis or at time of blood sampling. This adjustment increased the odds ratio to $1.51(95 \% \mathrm{Cl}, 0.82-2.78)$ for subjects with low free protein S levels and to $1.34(95 \%$ $\mathrm{Cl}, 0.74-2.44)$ in subjects with low total protein S levels when compared with subjects with levels in the $2.5^{\text {th }}-97.5^{\text {th }}$ percentile (Table 3). If protein S levels are somehow correlated with 
lifestyle, patients and partners may have been overmatched. To analyze if this occurred, we compared patients with RDD controls only. Risk estimates for the higher levels of free protein $S$ were somewhat higher than when RDD and partner controls were combined. For the lower (free) protein S levels, however, risk estimates remained close to 1.0 .

When we classified subjects into different percentiles (Table 4), again no increases in risks for venous thrombosis were observed for lower levels of free and total protein S.

When we restricted the analysis to subjects who did not change hormone use status between thrombosis and blood draw, i.e., either consistently used hormones at both time points, or did not use hormones at either time point, these odds ratios were $1.12(95 \% \mathrm{Cl}$, $0.69-1.81)$, and $0.83(95 \% \mathrm{Cl}, 0.48-1.44)$, respectively. In men, the odds ratio for venous thrombosis in those with low free protein $\mathrm{S}$ was $2.15(95 \% \mathrm{Cl}, 0.74-6.29)$. For total protein $\mathrm{S}$ levels, this odds ratio was $1.57(95 \% \mathrm{Cl}, 0.70-3.49)$. Interestingly, subjects with free protein S levels in the $>97.5^{\text {th }}$ percentile appeared to be at increased risk of venous thrombosis (odds ratio $1.55 ; 95 \% \mathrm{Cl}, 1.14-2.11$ ), which could only partly be attributed to overweight or obesity, as further adjustments for overweight or obesity attenuated this odds ratio to $1.48(95 \% \mathrm{Cl}$ 1.07-2.04) (data not shown).

To analyze if the results were sensitive to the cut-off level of free or total protein S, we subsequently compared decreasing cut-off values of free and total protein S levels, respectively, on the risk of venous thrombosis as compared to the reference group (subjects with protein S levels that were between the $2.5^{\text {th }}-97.5^{\text {th }}$ percentile). Although numbers became small, it appeared that a free protein $S$ cut off level of $<0.10^{\text {th }}$ (free protein $S<33 \mathrm{U} / \mathrm{dL}$ ) $0.20^{\text {th }}$ (free protein $\mathrm{S}<34 \mathrm{U} / \mathrm{dL}$ ) percentile could identify subjects at high risk of venous thrombosis (Figure 1A). Low, or even extremely low $\left(<0.20^{\text {th }}\right.$ percentile or total protein $S<53$ $\mathrm{U} / \mathrm{dL}$ ) total protein $\mathrm{S}$ levels were not associated with venous thrombosis (Figure 1B). Due to 
small numbers, the latter analysis could not be performed in subjects that were not pregnant or were not using hormones.

As shown in the cumulative distribution functions, patients had slightly higher free protein S levels (mean $100 \mathrm{U} / \mathrm{dL}$ in patients versus $94 \mathrm{U} / \mathrm{dL}$ in controls) and total protein $\mathrm{S}$ levels (mean $107 \mathrm{U} / \mathrm{dL}$ in patients versus $105 \mathrm{U} / \mathrm{dL}$ in controls) (Figure 2).

Increased risks for venous thrombosis in protein S deficient subjects are mainly reported from thrombophilic family studies. We therefore selected patients with a positive family history and repeated the analysis (Table 5). Again, no effects were apparent. These null findings could also not be explained by confounding of the common thrombophilias or by an interaction between the common thrombophilias and low levels of free and total protein S (Table 6).

Because vitamin $\mathrm{K}$ antagonist use was self-reported (and therefore we might have included subjects with low protein $\mathrm{S}$ levels that was due to unreported vitamin $\mathrm{K}$ antagonist treatment), we performed an additional sensitivity analysis by examining the distribution of the vitamin $\mathrm{K}$ dependent coagulant factors (i.e. factors II, VII, IX and X) in cases and control who did not report vitamin $\mathrm{K}$ antagonist usage. All factors were normally distributed, and there were no apparent outliers in the lower range, suggesting that self-reporting was reliable.

\section{Genetic analysis}

\section{Copy number variation}

We first tested samples from 2270 consecutive MEGA subjects (1395 patients and 875 controls). An abnormal MLPA pattern was detected in only one individual. This individual was a 66 years old female patient not using estrogens or vitamin $\mathrm{K}$ antagonists at the moment of thrombosis or sample collection. She had an unprovoked first venous thrombosis. Her family history was not available. The patient was heterozygous for a complete deletion of PROS1. 
Her total protein $\mathrm{S}$ was $64 \mathrm{U} / \mathrm{dL}\left(<2.5^{\text {th }}\right.$ percentile of the control group), and her free protein $\mathrm{S}$ was $22 \mathrm{U} / \mathrm{dL}\left(<2.5^{\text {th }}\right.$ percentile of the control group).

The presence of only one copy number variation in 2270 samples shows that such variation of PROS1 is at most a rare cause of venous thrombosis. To verify this, we zoomed in on potentially protein $S$ deficient subjects by selecting DNA from all subjects with low (i.e. lower than the $2.5^{\text {th }}$ percentile of the control group) total or low free protein S. Patients who used vitamin $\mathrm{K}$ antagonists at the time of the blood draw were also included to guarantee that protein S deficient subjects were not missed. In total, 191 samples were selected (84 patients and 107 controls), in which no new copy number variation of PROS1 was identified.

\section{Sequencing of PROS1}

To further investigate the molecular basis of protein S deficiency, we selected the 48 subjects with the lowest levels of free protein $\mathrm{S}$ (excluding patients using vitamin $\mathrm{K}$ antagonists). All these subjects were below the 1st percentile of the controls (cutoff $<46 \mathrm{U} / \mathrm{dL}$ ); of the 48 selected subjects 24 were patients and 24 were controls.

Eleven non-synonymous variations were identified in ten subjects ( 5 patients and 5 controls); one of these subjects (subject 25) is carrier of two different variations. Table 7 summarizes the results and gives references for variations previously described. Subjects are numbered according to increasing levels of free protein S. PROS1 coding DNA reference sequence is NM_000313.3 and protein reference sequence is NP_000304.2.

Four variations were novel. Subject 2 (patient) carried an indel mutation (Phe323fs) in the SHBG-like domain that is predicted to result in a truncated protein; subject 17 (patient) carried a $684 C>G$ (Cys228Trp) substitution in the EGF-domain 3; subject 12 (control) carried a nucleotide substitution in the 3'-UTR; and subject 45 (control) carried a 1095T>G (Asn365Lys) substitution in the SHBG-like domain. 
A complete deletion of PROS1 was detected in subject 4 (patient). Subject 6 is a patient who carried a 431C>A (Thr144Asn) substitution in the EFG-domain 1. Protein $S$ Heerlen (Ser501Ala) was detected in two control subjects (subjects 25 and 32), and one carrier of protein S Heerlen (subject 25) carried a second variation in the SHBG-like domain (13012T>C; Val434Ala). This variation is known as rs6803112 with a reported minor allele frequency (MAF) of 0.097 . Subject 43 (control) carried a 698G>A (Arg233Lys) substitution, which is also listed as rs41267007 (MAF 0.002). Finally, control subject 44 carried an $814 \mathrm{G}>\mathrm{A}$ (Gly272Arg) variation in the EGF-domain 4. This variation is listed as rs41267005 (MAF 0.002 ) but no information regarding protein $S$ levels is available. 


\section{DISCUSSION}

Conflicting data have been reported regarding venous thrombotic risk in subjects with protein $S$ deficiency within the community. ${ }^{2}$ In the present study, subjects with low levels of free protein $\mathrm{S}$ had an increased risk of unprovoked venous thrombosis (odds ratio $2.31 ; 95 \% \mathrm{Cl}$, 1.06-5.05). However, the prevalence of patients with such levels was low ( $n=8$, or $0.4 \%$ of the total patient population), making it impractical to use free protein $S$ levels to identify patients at risk in a clinical setting. The present study, confirms the results of a previous population based study $(\text { LETS })^{20}$, where only very low levels of free protein $S$ (i.e. $<0.10^{\text {th }}$ percentile or $<$ $33 \mathrm{U} / \mathrm{dL}$ ), but not of total protein $\mathrm{S}$, were associated with an increased risk for venous thrombosis (odds ratio $5.44 ; 95 \% \mathrm{Cl}, 0.61-48.78$ ). This increased risk at very low free protein $S$ levels corresponds with findings from family studies of protein $S$ deficiency on venous thrombosis risk (although relative risk estimates in family studies for first venous thrombosis in subjects with very low free protein $S$ levels are even higher than 5$)^{12,30}$, as well as with findings from family studies that showed that the cut off level of free protein $S$ to identify true inherited protein $S$ deficiency lies far below the commonly used normal range. ${ }^{12,14}$

Total protein S levels were not able to identify subjects at risk of venous thrombosis even when these levels were very low. This is in agreement with studies where free protein S was a better indicator of venous thrombosis risk than total protein S. ${ }^{31}$ Nevertheless, as shown by its broad confidence interval, this analysis suffers from small sample size ( $n=7$ of the patient population), indicating that even if very low free protein $S$ levels are associated with venous thrombosis, large numbers of patients with venous thrombosis will need to be tested to identify only a few with a true free protein S deficiency. Such a strategy is unlikely to become clinically useful.

Many patients with venous thrombosis who are on anticoagulant treatment at the time of the blood sampling are identified with a protein S deficiency, which is thought to have 
clinical consequences. ${ }^{17,32}$ However, both our study and previous studies show reduced protein $\mathrm{S}$ levels in vitamin $\mathrm{K}$ antagonist and oral contraceptive users in the absence of a known true (genetic) deficiency. ${ }^{33,34}$ This reinforces the importance of avoiding the collection of blood for protein $\mathrm{S}$ measurements at moments when acquired deficiency can be present.

Molecular analysis of PROS1 in 48 subjects with very low levels of protein S (below the $1^{\text {st }}$ percentile) identified mutations in only ten subjects. This finding suggests that inherited protein $\mathrm{S}$ deficiency is rare in the general population and in patients with thrombosis. Please note, however, that our analysis was limited to copy number variations, exons and their flanking regions, and the 5'- and 3'-UT regions. We cannot exclude that genetic variations in introns or in promoter regions could play a role in protein S deficiency.

Mutations were equally distributed among patients and controls. Three out of six patients with protein S levels below percentile 0.2 carried mutations that are likely to be detrimental (complete deletion of PROS1, 967delTinsGG and Thr144Asn). In contrast, mutations in controls were likely not to be detrimental. Protein S Heerlen (known to be associated with type III protein S deficiency) was detected in two controls. Another control carried a variation described before as a neutral polymorphism (Arg233Lys) and a final control carried a variation in the 3'-UT region.

PROS1 deletion was present in only one patient, showing that gross copy number variation of $P R O S 1$ is rare in the general population.

Some aspects of our study need additional comment. First, we have noted that high levels of free protein $\mathrm{S}$ were associated with an increased risk of venous thrombosis. High levels of free protein $S$ have been associated with an increased risk of coronary heart disease in another study. ${ }^{35}$ Free protein $\mathrm{S}$ has been described as a semi-delayed acute phase reactant ${ }^{19,36}$, and protein $S$ levels were found top be higher in overweight/obese subjects than in subjects with normal weight. ${ }^{24}$ Obesity is associated with a chronic inflammatory status and 
with increased risk for venous thrombosis ${ }^{37}$. It is possible that high levels of free protein $S$ are a consequence of the former. However, adjustment for overweight/obesity only attenuated the risk of venous thrombosis associated with high levels of free protein S, suggesting that other mechanisms could play a role.

Second, our study is a case-control study in which the blood sample was collected after the thrombotic event. Therefore, the possibility that differences in plasma levels of protein $\mathrm{S}$ in patients and control subjects were the result of the thrombotic event itself cannot be excluded. However, the blood draw was performed at least 3 months after the thrombotic event, and it is unlikely that the thrombotic event itself caused persistent abnormalities in protein S levels. Furthermore, no differences in protein S levels were observed between patients in whom blood was drawn 3-6 months after their thrombotic event compared with those in whom the blood draw took place later (e.g. more than 6-9, 9-12 or $>12$ months).

Third, free and total protein S were only measured once. This may have led to misclassification of protein S deficiency when protein S levels fluctuate due to transient acquired conditions. However, only use of female hormones and vitamin $\mathrm{K}$ antagonists are known determinants of protein S levels. Sensitivity analyses in which oral contraceptive users, and pregnant or puerperic women were excluded did not materially affect the risk estimates for total protein S, but did slightly for free protein S. Moreover, subjects who were still on vitamin $\mathrm{K}$ antagonists at time of blood draw were excluded from analyses where relative risk estimates where determined.

Finally, qualitative analysis of protein $\mathrm{S}$ was not performed, as the laboratory analysis of protein $\mathrm{S}$ activity levels is known to produce spurious false low levels. Therefore, we may have missed individuals with type II protein S deficiency. ${ }^{38}$

In summary, low free protein $\mathrm{S}$ and low total protein $\mathrm{S}$ levels could at best rarely identify subjects at risk for venous thrombosis in a population-based study. Only when cut off 
levels for free protein $\mathrm{S}$ were far below the normal range or when unprovoked venous thrombosis was considered as outcome event, we found a 2- to 5-fold increased risk of venous thrombosis. Protein $\mathrm{S}$ testing and subsequent testing on PROS1 mutations should therefore not be considered in unselected patients with venous thrombosis. 


\section{Acknowledgement}

This study and the MEGA study were supported by the Netherlands Heart Foundation (NHS 2006B160 and NHS 98.113), the Dutch Cancer Foundation (RUL 99/1992) and the Netherlands Organisation for Scientific Research (912-09-033-2003). DDR was supported by CAPES (Edital DRI/CGCI/006/2009). WML is a Postdoctoral Fellow of the Netherlands Heart Foundation (2011T12). The authors are grateful to Aat van Wijngaarden for his assistance in PROS1 sequencing, and Rob van Eck for measuring protein S.

\section{Authorship Contributions}

MCP performed laboratory analysis, interpreted the data and drafted the manuscript. DDR had full access to the database, performed statistical analysis and drafted the manuscript. IDB collected data for the MEGA study, had full access to the database and contributed to the analysis. AAG standardized the MLPA method and revised the manuscript. MCHV discussed the results and revised the manuscript. CJMD collected data for the MEGA study and revised the manuscript. WML had full access to the database, supervised statistical analysis and revised the manuscript. PHR conceived and designed the present study, analyzed the data, and revised the manuscript. FRR designed the MEGA study and revised the manuscript.

\section{Conflict of Interest Disclosures}

The authors declare no competing financial interests. 


\section{REFERENCES}

1. Fair DS, Marlar RA. Biosynthesis and secretion of factor VII, protein C, protein S, and the Protein C inhibitor from a human hepatoma cell line. Blood. 1986;67(1):64-70.

2. Dahlbäck B. The tale of protein $S$ and $C 4 b$-binding protein, a story of affection. Thromb Haemost. 2007;98(1):90-96.

3. Walker FJ. Protein S and the regulation of activated protein C. Seminars in thrombosis and hemostasis. 1984;10(2):131-138.

4. Hackeng TM, Sere KM, Tans G, Rosing J. Protein S stimulates inhibition of the tissue factor pathway by tissue factor pathway inhibitor. Proceedings of the National Academy of Sciences of the United States of America. 2006;103(9):3106-3111.

5. Castoldi E, Maurissen LF, Tormene D, et al. Similar hypercoagulable state and thrombosis risk in type I and type III protein S-deficient individuals from families with mixed type I/III protein S deficiency. Haematologica. 2010;95(9):1563-1571.

6. Bertina RM. Nomenclature proposal for protein S deficiency. XXXVI Annual Meeting of Scientific and Standardization Committee of the International Society for Thrombosis and Haemostasis. 1990;June, Barcelona, Spain.

7. Gandrille S, Borgel D, Sala N, et al. Protein S deficiency: a database of mutations-summary of the first update. Thrombosis and haemostasis. 2000;84(5):918.

8. García de Frutos P, Fuentes-Prior P, Hurtado B, Sala N. Molecular basis of protein S deficiency. Thromb Haemost. 2007;98(3):543-556.

9. Stenson PD, Mort M, Ball EV, et al. The Human Gene Mutation Database: 2008 update. Genome medicine. 2009;1(1):13.

10. Johansson AM, Hillarp A, Säll T, Zöller B, Dahlbäck B, Halldén C. Large deletions of the PROS1 gene in a large fraction of mutation-negative patients with protein S deficiency. Thromb Haemost. 2005;94(5):951-957. 
11. Pintao MC, Garcia AA, Borgel D, et al. Gross deletions/duplications in PROS1 are relatively common in point mutation-negative hereditary protein S deficiency. Hum Genet. 2009;126(3):449-456.

12. Makris M, Leach M, Beauchamp NJ, et al. Genetic analysis, phenotypic diagnosis, and risk of venous thrombosis in families with inherited deficiencies of protein S. Blood. 2000;95(6):1935-1941.

13. Ten Kate MK, Platteel M, Mulder R, et al. PROS1 analysis in 87 pedigrees with hereditary protein S deficiency demonstrates striking genotype-phenotype associations. Hum Mutat. 2008;29(7):939-947.

14. Lijfering WM, Mulder R, ten Kate MK, Veeger NJ, Mulder AB, van der Meer J. Clinical relevance of decreased free protein S levels: results from a retrospective family cohort study involving 1143 relatives. Blood. 2009;113(6):1225-1230.

15. Vossen CY, Conard J, Fontcuberta J, et al. Risk of a first venous thrombotic event in carriers of a familial thrombophilic defect. The European Prospective Cohort on Thrombophilia (EPCOT). Journal of thrombosis and haemostasis : JTH. 2005;3(3):459464.

16. Vossen CY, Walker ID, Svensson P, et al. Recurrence rate after a first venous thrombosis in patients with familial thrombophilia. Arteriosclerosis, thrombosis, and vascular biology. 2005;25(9):1992-1997.

17. Lijfering WM, Brouwer JL, Veeger NJ, et al. Selective testing for thrombophilia in patients with first venous thrombosis: results from a retrospective family cohort study on absolute thrombotic risk for currently known thrombophilic defects in 2479 relatives. Blood. 2009;113(21):5314-5322. 
18. Zöller B, Berntsdotter A, García de Frutos P, Dahlbäck B. Resistance to activated protein $\mathrm{C}$ as an additional genetic risk factor in hereditary deficiency of protein S. Blood. 1995;85(12):3518-3523.

19. Faioni EM, Valsecchi C, Palla A, Taioli E, Razzari C, Mannucci PM. Free protein S deficiency is a risk factor for venous thrombosis. Thromb Haemost. 1997;78(5):1343-1346.

20. Koster T, Rosendaal FR, Briët E, et al. Protein C deficiency in a controlled series of unselected outpatients: an infrequent but clear risk factor for venous thrombosis (Leiden Thrombophilia Study). Blood. 1995;85(10):2756-2761 .

21. Liberti G, Bertina RM, Rosendaal FR. Hormonal state rather than age influences cut-off values of protein S: reevaluation of the thrombotic risk associated with protein S deficiency. Thromb Haemost. 1999;82(3):1093-1096.

22. Blom JW, Doggen CJ, Osanto S, Rosendaal FR. Malignancies, prothrombotic mutations, and the risk of venous thrombosis. JAMA : the journal of the American Medical Association. 2005;293(6):715-722.

23. Schouten JP, McElgunn CJ, Waaijer R, Zwijnenburg D, Diepvens F, Pals G. Relative quantification of 40 nucleic acid sequences by multiplex ligation-dependent probe amplification. Nucleic Acids Res. 2002;30(12):e57.

24. Mulder R, van Schouwenburg IM, Mahmoodi BK, et al. Associations between high factor VIII and low free protein S levels with traditional arterial thrombotic risk factors and their risk on arterial thrombosis: results from a retrospective family cohort study. Thrombosis research. 2010;126(4):e249-254.

25. Henkens CM, Bom VJ, Van der Schaaf W, et al. Plasma levels of protein S, protein C, and factor X: effects of sex, hormonal state and age. Thrombosis and haemostasis. 1995;74(5):1271-1275.

26. Knol MJ, Vandenbroucke JP, Scott P, Egger M. What do case-control studies 
estimate? Survey of methods and assumptions in published case-control research. Am J Epidemiol. 2008;168(9):1073-81.

27. Middeldorp S, Meijers JC, van den Ende AE, et al. Effects on coagulation of levonorgestrel- and desogestrel-containing low dose oral contraceptives: a cross-over study. Thrombosis and haemostasis. 2000;84(1):4-8.

28. Said JM, Ignjatovic V, Monagle PT, Walker SP, Higgins JR, Brennecke SP. Altered reference ranges for protein $\mathrm{C}$ and protein $\mathrm{S}$ during early pregnancy: Implications for the diagnosis of protein $\mathrm{C}$ and protein $\mathrm{S}$ deficiency during pregnancy. Thrombosis and haemostasis. 2010;103(5):984-988.

29. Castoldi E, Hackeng TM. Regulation of coagulation by protein S. Curr Opin Hematol. 2008;15(5):529-536 .

30. Mulder R, Ten Kate MK, Kluin-Nelemans HC, Mulder AB. Low cut-off values increase diagnostic performance of protein S assays. Thrombosis and haemostasis. 2010;104(3):618-625.

31.ten Kate MK, van der Meer J. Protein S deficiency: a clinical perspective. Haemophilia : the official journal of the World Federation of Hemophilia. 2008;14(6):1222-1228.

32. Brouwer JL, Lijfering WM, Ten Kate MK, Kluin-Nelemans HC, Veeger NJ, van der Meer J. High long-term absolute risk of recurrent venous thromboembolism in patients with hereditary deficiencies of protein S, protein $\mathrm{C}$ or antithrombin. Thrombosis and haemostasis. 2009;101(1):93-99.

33. Tans G, Curvers J, Middeldorp S, et al. A randomized cross-over study on the effects of levonorgestrel- and desogestrel-containing oral contraceptives on the anticoagulant pathways. Thrombosis and haemostasis. 2000;84(1):15-21. 
34. Hansen AT, Andreasen BH, Salvig JD, Hvas AM. Changes in fibrin D-dimer, fibrinogen, and protein S during pregnancy. Scandinavian journal of clinical and laboratory investigation. 2011;71(2):173-176.

35. Ken-Dror G, Cooper JA, Humphries SE, Drenos F, Ireland HA. Free protein S level as a risk factor for coronary heart disease and stroke in a prospective cohort study of healthy United Kingdom men. American journal of epidemiology. 2011;174(8):958-968.

36. Toulon P, Gandrille S, Vitoux JF, Fiessinger JN, Sultan Y, Aiach M. High total and free protein $\mathrm{S}$ in patients with acute deep vein thrombosis. Thrombosis research. 1990;59(1):213-217.

37. Darvall KA, Sam RC, Silverman SH, Bradbury AW, Adam DJ. Obesity and thrombosis. European journal of vascular and endovascular surgery : the official journal of the European Society for Vascular Surgery. 2007;33(2):223-233.

38. Goodwin AJ, Rosendaal FR, Kottke-Marchant K, Bovill EG. A review of the technical, diagnostic, and epidemiologic considerations for protein S assays. Arch Pathol Lab Med. 2002;126(11):1349-1366.

39. Gandrille S, Borgel D, Eschwege-Gufflet V, et al. Identification of 15 different candidate causal point mutations and three polymorphisms in 19 patients with protein S deficiency using a scanning method for the analysis of the protein S active gene. Blood. 1995;85(1):130-138.

40. Borgel D, Duchemin J, Alhenc-Gelas M, Matheron C, Aiach M, Gandrille S. Molecular basis for protein S hereditary deficiency: genetic defects observed in 118 patients with type I and type Ila deficiencies. The French Network on Molecular Abnormalities Responsible for Protein C and Protein S Deficiencies. J Lab Clin Med. 1996;128(2):218227. 
41. Espinosa-Parrilla Y, Yamazaki T, Sala N, Dahlback B, de Frutos PG. Protein S secretion differences of missense mutants account for phenotypic heterogeneity. Blood. 2000;95(1):173-179.

42. Rezende SM, Lane DA, Zoller B, et al. Genetic and phenotypic variability between families with hereditary protein S deficiency. Thromb Haemost. 2002;87(2):258-265.

43. den Dunnen JT, Antonarakis SE. Mutation nomenclature extensions and suggestions to describe complex mutations: a discussion. Human mutation. 2000;15(1):7-12.

44. Bezemer ID, van der Meer FJ, Eikenboom JC, Rosendaal FR, Doggen CJ. The value of family history as a risk indicator for venous thrombosis. Arch Intern Med. 2009.23;169(6):610-5. 
Table 1. Clinical characteristics

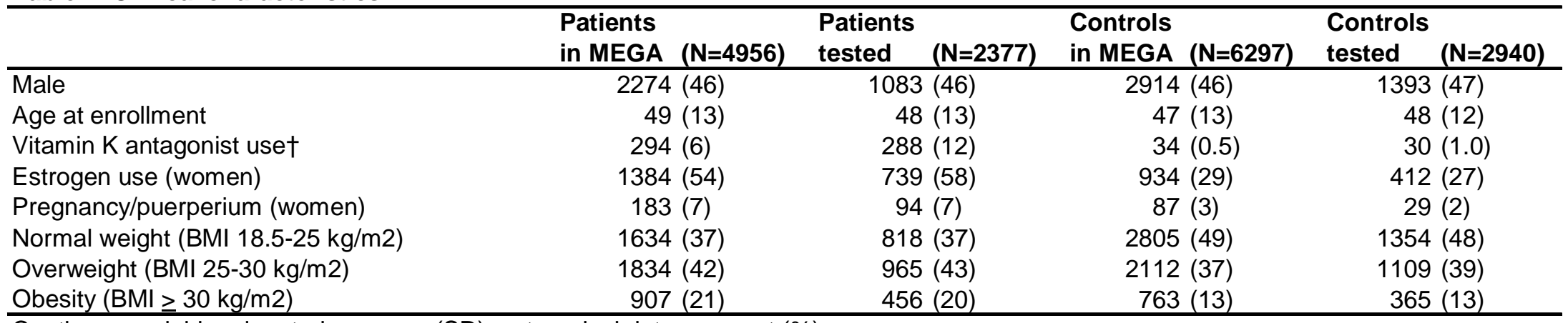

Continous variables denoted as mean (SD), categorical data as count (\%).

Data were missing for some participants in some subgroups

* There were slightly less patients $(n=2331)$ and controls $(n=2872)$ tested on free protein $S$ due to sampling errors.

1 † At time of blood draw. 
Table 2. Association of protein $\mathrm{S}$ with venous thrombotic risk factors in control subjects

\begin{tabular}{|c|c|c|c|c|c|c|c|c|}
\hline & \multicolumn{3}{|c|}{$\begin{array}{l}\text { Free protein S } \\
\end{array}$} & & \multicolumn{3}{|c|}{ Total protein S } & \multirow[b]{2}{*}{$\begin{array}{l}\text { Mean difference } \\
(95 \% \mathrm{Cl})\end{array}$} \\
\hline & $\begin{array}{l}\text { Subjects } \\
\text { (N) }\end{array}$ & $\begin{array}{l}\text { Mean level } \\
(\mathrm{U} / \mathrm{dL})\end{array}$ & $\begin{array}{l}\text { Mean difference* } \\
(95 \% \mathrm{Cl})\end{array}$ & $\begin{array}{l}\text { Mean difference } † \\
(95 \% \mathrm{Cl})\end{array}$ & $\begin{array}{l}\text { Subjects } \\
\text { (N) }\end{array}$ & $\begin{array}{l}\text { Mean level } \\
(\mathrm{U} / \mathrm{dL})\end{array}$ & $\begin{array}{l}\text { Mean difference } \\
(95 \% \mathrm{Cl}) \\
\end{array}$ & \\
\hline No vitamin $\mathrm{K}$ antagonists & 2858 & 92 & Reference & Reference & 2910 & 102 & Reference & Reference \\
\hline Vitamin $\mathrm{K}$ antagonists & 14 & 44 & $-50(-61$ to -39$)$ & $-52(-62$ to -41$)$ & 30 & 62 & $-37(-48$ to -28$)$ & $(-40(-49$ to -30$)$ \\
\hline Non-estrogen users (women) & 1067 & 88 & Reference & Reference & 1097 & 105 & Reference & Reference \\
\hline Estrogen users (women) & 408 & 79 & $-4(-6$ to -1$)$ & $-7(-9$ to -5$)$ & 412 & 89 & $-9(-12$ to -7$)$ & $-11(-13$ to -9$)$ \\
\hline No pregnancy/puerperium (women) & 1473 & 86 & Reference & Reference & 1505 & 101 & Reference & Reference \\
\hline Pregnancy/puerperium (women) & 28 & 70 & $-6(-13$ to 2$)$ & $-14(-21$ to -6$)$ & 29 & 89 & $1(-6$ to 8$)$ & $-7(-14$ to -0.1$)$ \\
\hline Normal weight & 1332 & 87 & Reference & Reference & 1354 & 98 & Reference & Reference \\
\hline Overweight & 1072 & 96 & 6 (4 to 7$)$ & 6 (4 to 7$)$ & 1109 & 105 & 5 (4 to 7$)$ & 5 (3 to 6$)$ \\
\hline Obesity & 358 & 97 & $8(6$ to 11$)$ & $8(6$ to 11$)$ & 365 & 108 & $8(6$ to 10$)$ & $8(5$ to 10$)$ \\
\hline
\end{tabular}

* Adjusted for age and sex where applicable.

† Adjusted for age, sex (where applicable), and the effects of all other factors in the table. 


\begin{tabular}{|c|c|c|c|c|c|}
\hline & \multirow[b]{2}{*}{ Patients, n (\%) } & \multirow[b]{2}{*}{ Controls, n (\%) } & \multicolumn{3}{|c|}{ Odds ratio $(95 \% \mathrm{Cl})^{\star}$} \\
\hline & & & Overall & Overall minust & Overall minus $\ddagger$ \\
\hline \multicolumn{6}{|l|}{ Total } \\
\hline \multicolumn{6}{|l|}{ Free protein S antigen } \\
\hline > 97.5th percentile (> $139 \mathrm{U} / \mathrm{dL})$ & $88(4.3)$ & $83(2.9)$ & $1.55(1.14-2.11)$ & $1.81(1.31-2.50)$ & $5.82(3.14-10.78)$ \\
\hline 97.5th-2.5th percentile (53 - $139 \mathrm{U} / \mathrm{dL})$ & $1937(94)$ & $2705(95)$ & Reference & Reference & Reference \\
\hline$<2.5$ th percentile $(<53 \mathrm{U} / \mathrm{dL})$ & $44(2.1)$ & $70(2.4)$ & $0.82(0.56-1.21)$ & $1.51(0.82-2.78)$ & $1.04(0.54-2.01)$ \\
\hline \multicolumn{6}{|l|}{ Total protein S antigen } \\
\hline$>$ 97.5th percentile $(>146 \mathrm{U} / \mathrm{dL})$ & $422.0)$ & $72(2.5)$ & $0.82(0.56-1.21)$ & $1.00(0.66-1.53)$ & $1.02(0.62-1.68)$ \\
\hline 97.5th-2.5th percentile (68 - $146 \mathrm{U} / \mathrm{dL})$ & $1997(96)$ & $2766(95)$ & Reference & Reference & Reference \\
\hline$<2.5$ th percentile $(<68 \mathrm{U} / \mathrm{dL})$ & $50(2.4)$ & $72(2.5)$ & $0.92(0.63-1.33)$ & $1.34(0.74-2.44)$ & $1.49(0.71-3.11)$ \\
\hline \multicolumn{6}{|l|}{ Unprovoked } \\
\hline \multicolumn{6}{|l|}{ Free protein S antigen } \\
\hline > 97.5th percentile (> $139 \mathrm{U} / \mathrm{dL})$ & $33(6)$ & $83(2.9)$ & $1.74(1.13-2.67)$ & $1.72(1.12-2.65)$ & $1.86(1.19-2.89)$ \\
\hline 97.5th-2.5th percentile (53 - $139 \mathrm{U} / \mathrm{dL})$ & $504(92)$ & $2705(95)$ & Reference & Reference & Reference \\
\hline$<2.5$ th percentile $(<53 \mathrm{U} / \mathrm{dL})$ & $8(1.5)$ & $70(2.4)$ & $1.77(0.84-3.71)$ & $2.31(1.06-5.05)$ & $1.80(0.80-4.01)$ \\
\hline \multicolumn{6}{|l|}{ Total protein S antigen } \\
\hline > 97.5th percentile (> $146 \mathrm{U} / \mathrm{dL})$ & $16(2.9)$ & $72(2.5)$ & $1.21(0.70-2.10)$ & $1.15(0.66-2.00)$ & $1.14(0.65-2.00)$ \\
\hline 97.5th-2.5th percentile (68 - $146 \mathrm{U} / \mathrm{dL})$ & $524(94)$ & $2766(95)$ & Reference & Reference & Reference \\
\hline$\leq 2.5$ th percentile $(<68 \mathrm{U} / \mathrm{dL})$ & $19(3.4)$ & $72(2.5)$ & $1.19(0.55-2.57)$ & $1.59(0.71-3.58)$ & $1.75(0.79-3.85)$ \\
\hline \multicolumn{6}{|l|}{ Provoked^ } \\
\hline \multicolumn{6}{|l|}{ Free protein S antigen } \\
\hline > 97.5th percentile (> $139 \mathrm{U} / \mathrm{dL})$ & $55(3.8)$ & $83(2.9)$ & $1.61(1.12-2.30)$ & $1.91(1.30-2.80)$ & $3.62(2.20-5.96)$ \\
\hline 97.5th-2.5th percentile (53 - $139 \mathrm{U} / \mathrm{dL})$ & $1390(94)$ & $2705(95)$ & Reference & Reference & Reference \\
\hline$<2.5$ th percentile $(<53 \mathrm{U} / \mathrm{dL})$ & $35(2.4)$ & $70(2.4)$ & $0.69(0.45-1.05)$ & $1.17(0.53-2.58)$ & $1.08(0.49-2.39)$ \\
\hline \multicolumn{6}{|l|}{ Total protein S antigen } \\
\hline > 97.5th percentile (> $146 \mathrm{U} / \mathrm{dL})$ & $26(1.7)$ & $72(2.5)$ & $0.74(0.47-1.18)$ & $0.95(0.56-1.59)$ & $1.05(0.60-1.83)$ \\
\hline 97.5th-2.5th percentile (68 - $146 \mathrm{U} / \mathrm{dL})$ & $1431(96)$ & $2766(95)$ & Reference & Reference & Reference \\
\hline$\leq 2.5$ th percentile $(<68 \mathrm{U} / \mathrm{dL})$ & $39(2.6)$ & $72(2.5)$ & $0.78(0.52-1.17)$ & $1.14(0.54-2.43)$ & $1.26(0.55-2.91)$ \\
\hline
\end{tabular}

* Adjusted for age and sex

$\dagger$ Estrogen users or pregnancy/puerperium

¥ Minus estrogen users or pregancy/puerperium. Control group confined to random digit dialing subjects only.

$\wedge$ Provoked venous thrombosis classified as thrombosis due to trauma, plaster cast use, surgery,

pregnancy/puerperium, or immobilization, within three months prior to the index date,

$>4$ hours travelling by air, train, bus, or car in the 8 weeks before the index date,

estrogen/progestagen use at time of the index date, and diagnosis of malignancy within five years 
Table 4. Risk of venous thrombosis for strata of protein S levels

\begin{tabular}{|c|c|c|c|c|}
\hline \multirow[t]{2}{*}{ Measurement } & \multirow[b]{2}{*}{ Patients, n (\%) } & \multirow[b]{2}{*}{ Controls, n (\%) } & \multicolumn{2}{|c|}{$\begin{array}{l}\text { Total } \\
\text { Odds ratio }(95 \% \mathrm{Cl})^{\star}\end{array}$} \\
\hline & & & Overall & Overall minust \\
\hline \multicolumn{5}{|l|}{ Free protein S antigen } \\
\hline 50th-75th percentile (91 - $105 \mathrm{U} / \mathrm{dL})$ & $528(26.7)$ & $692(25.0)$ & $0.85(0.72-1.00)$ & $0.77(0.64-0.92)$ \\
\hline 25th-50th percentile (77 - $91 \mathrm{U} / \mathrm{dL})$ & $507(25.6)$ & $738(26.6)$ & $0.81(0.69-0.96)$ & $0.70(0.57-0.85)$ \\
\hline \multicolumn{5}{|l|}{ Total protein S antigen } \\
\hline 97.5th-75th percentile (115 - $146 \mathrm{U} / \mathrm{dL})$ & $498(24.3)$ & $653(23.0)$ & Reference & Reference \\
\hline 50th-75th percentile (101 - $115 \mathrm{U} / \mathrm{dL})$ & $573(28.0)$ & $720(25.4)$ & $1.02(0.86-1.19)$ & $0.99(0.82-1.19)$ \\
\hline 25th-50th percentile (89 - $101 \mathrm{U} / \mathrm{dL})$ & $500(24.4)$ & $723(25.5)$ & $0.85(0.72-1.01)$ & $0.73(0.60-0.89)$ \\
\hline 10-25th percentile (78 - $89 \mathrm{U} / \mathrm{dL})$ & $296(14.5)$ & $470(16.6)$ & $0.79(0.65-0.97)$ & $0.68(0.53-0.88)$ \\
\hline
\end{tabular}

\footnotetext{
* Adjusted for age and sex

† Estrogen users or pregnancy/puerperium
} 
Table 5. Risk of venous thrombosis for high or low levels of protein S, according to family history

\begin{tabular}{|c|c|c|c|c|}
\hline & \multirow[b]{2}{*}{ Patients, n } & \multirow[b]{2}{*}{ Controls, $\mathbf{n}$} & \multicolumn{2}{|c|}{ Odds ratio $(95 \% \mathrm{Cl})^{*}$} \\
\hline & & & Overall & Overall minus \\
\hline \multicolumn{5}{|l|}{ Negative family history } \\
\hline \multicolumn{5}{|l|}{ Free protein S antigen } \\
\hline 97.5th-2.5th percentile (53 - $139 \mathrm{U} / \mathrm{dL})$ & 936 & 2705 & Reference & Reference \\
\hline$<2.5$ th percentile $(<53 \mathrm{U} / \mathrm{dL})$ & 24 & 70 & $0.75(0.46-1.21)$ & $1.95(0.93-4.05)$ \\
\hline \multicolumn{5}{|l|}{ Total protein S antigen } \\
\hline 97.5th-2.5th percentile (68 - $146 \mathrm{U} / \mathrm{dL})$ & 964 & 2766 & Reference & Reference \\
\hline$<2.5$ th percentile $(<68 \mathrm{U} / \mathrm{dL})$ & 21 & 72 & $0.65(0.40-1.07)$ & $1.41(0.66-3.00)$ \\
\hline \multicolumn{5}{|l|}{ Positive family history } \\
\hline \multicolumn{5}{|l|}{ Free protein S antigen } \\
\hline 97.5th-2.5th percentile (53 - $139 \mathrm{U} / \mathrm{dL})$ & 524 & 2705 & Reference & Reference \\
\hline$<2.5$ th percentile $(<53 \mathrm{U} / \mathrm{dL})$ & 10 & 70 & $0.86(0.44-1.70)$ & $0.92(0.27-3.08)$ \\
\hline \multicolumn{5}{|l|}{ Total protein S antigen } \\
\hline 97.5th-2.5th percentile (68 - $146 \mathrm{U} / \mathrm{dL})$ & 540 & 2766 & Reference & Reference \\
\hline$<2.5$ th percentile $(<68 \mathrm{U} / \mathrm{dL})$ & 12 & 72 & $1.00(0.53-1.86)$ & $1.08(0.37-3.15)$ \\
\hline
\end{tabular}

* Adjusted for age and sex

† Estrogen users or pregnancy/puerperium 
Table 6. Risk of venous thrombosis for low levels of protein S, startified analysis with common thrombophilias

\begin{tabular}{|c|c|c|c|c|}
\hline & & Patients, n (\%) & Controls, n (\%) & Odds ratio $(95 \% \mathrm{Cl})^{\star}$ \\
\hline Free protein $\mathrm{S}$ antigen & Blood group non-O & & & \\
\hline 97.5th-2.5th percentile (53 - $139 \mathrm{U} / \mathrm{dL}$ ) & Absent & $556(28.1)$ & $1270(45.9)$ & Reference \\
\hline$<2.5$ th percentile $(<53 \mathrm{U} / \mathrm{dL})$ & Absent & $13(0.7)$ & $30(1.1)$ & $0.93(0.48-1.79)$ \\
\hline 97.5th-2.5th percentile (53 - $139 \mathrm{U} / \mathrm{dL})$ & Present & $1378(69.7)$ & $1429(51.6)$ & $2.21(1.95-2.50)$ \\
\hline$<2.5$ th percentile $(<53 \mathrm{U} / \mathrm{dL})$ & Present & $31(1.6)$ & $39(1.4)$ & $1.71(1.05-2.78)$ \\
\hline Total protein S antigen & Blood group non-O & & & \\
\hline 97.5th-2.5th percentile $(68-146 \mathrm{U} / \mathrm{dL})$ & Absent & $575(28.1)$ & $1300(45.9)$ & Reference \\
\hline$<2.5$ th percentile $(<68 \mathrm{U} / \mathrm{dL})$ & Absent & $13(0.6)$ & $32(1.1)$ & $0.86(0.45-1.65)$ \\
\hline 97.5th-2.5th percentile $(68-146 \mathrm{U} / \mathrm{dL})$ & Present & $1418(69.4)$ & $1459(51.5)$ & $2.20(1.95-2.49)$ \\
\hline$<2.5$ th percentile $(<68 \mathrm{U} / \mathrm{dL})$ & Present & $37(1.8)$ & $40(1.4)$ & $2.00(1.27-3.18)$ \\
\hline Free protein S antigen & Factor V Leiden & & & \\
\hline 97.5th-2.5th percentile (53 - $139 \mathrm{U} / \mathrm{dL})$ & Absent & $1633(82.5)$ & 2578 (92.9) & Reference \\
\hline$<2.5$ th percentile $(<53 \mathrm{U} / \mathrm{dL})$ & Absent & $42(2.1)$ & $66(2.4)$ & $0.94(0.63-1.40)$ \\
\hline 97.5th-2.5th percentile (53 - $139 \mathrm{U} / \mathrm{dL}$ ) & Present & $303(15.3)$ & $127(4.6)$ & $3.79(3.05-4.71)$ \\
\hline$<2.5$ th percentile $(<53 \mathrm{U} / \mathrm{dL})$ & Present & $2(0.1)$ & $4(0.1)$ & $0.79(0.14-4.33)$ \\
\hline Total protein S antigen & Factor V Leiden & & & \\
\hline 97.5th-2.5th percentile $(68-146 \mathrm{U} / \mathrm{dL})$ & Absent & 1689 (82.6) & $2630(92.7)$ & Reference \\
\hline$<2.5$ th percentile $(<68 \mathrm{U} / \mathrm{dL})$ & Absent & $44(2.2)$ & $69(2.4)$ & $0.94(0.64-1.39)$ \\
\hline 97.5th-2.5th percentile $(68-146 \mathrm{U} / \mathrm{dL})$ & Present & $307(15.0)$ & $136(4.8)$ & $3.35(2.86-4.37)$ \\
\hline$<2.5$ th percentile $(<68 \mathrm{U} / \mathrm{dL})$ & Present & $6(0.3)$ & $3(0.1)$ & $2.99(0.75-12.0)$ \\
\hline Free protein S antigen & Prothrombin G20210A & & & \\
\hline 97.5th-2.5th percentile $(53-139 \mathrm{U} / \mathrm{dL}$ ) & Absent & $1843(93.0)$ & $2658(958)$ & Reference \\
\hline$<2.5$ th percentile $(<53 \mathrm{U} / \mathrm{dL})$ & Absent & $42(2.2)$ & 69 (2.5) & $0.84(0.57-1.24)$ \\
\hline 97.5th-2.5th percentile $(53-139 \mathrm{U} / \mathrm{dL}$ ) & Present & $94(4.7)$ & $47(1.7)$ & $2.87(2.01-4.09)$ \\
\hline$<2.5$ th percentile $(<53 \mathrm{U} / \mathrm{dL})$ & Present & $1(0.1)$ & $1(0.0)$ & $1.46(0.09-23.4)$ \\
\hline Total protein S antigen & Prothrombin G20210A & & & \\
\hline 97.5th-2.5th percentile $(68-146 \mathrm{U} / \mathrm{dL})$ & Absent & 1905 (93.1) & $2718(95.8)$ & Reference \\
\hline$<2.5$ th percentile $(<68 \mathrm{U} / \mathrm{dL})$ & Absent & $48(2.3)$ & $70(2.5)$ & $0.93(0.61-1.35)$ \\
\hline 97.5th-2.5th percentile $(68-146 \mathrm{U} / \mathrm{dL})$ & Present & $92(4.5)$ & $48(1.7)$ & $2.73(1.92-3.89)$ \\
\hline$<2.5$ th percentile $(<68 \mathrm{U} / \mathrm{dL})$ & Present & $2(0.1)$ & $2(0.1)$ & $1.37(0.19-9.78)$ \\
\hline
\end{tabular}

$\leq 2.5$ th percentile $(<68 \mathrm{U} / \mathrm{dL})$ 
Table 7. Molecular analysis of PROS1 in subjects with free protein $S$ level bellow $1^{\text {st }}$ percentile, as determined in MEGA controls

\begin{tabular}{|c|c|c|c|c|c|c|c|}
\hline $\begin{array}{l}\text { Subject } \\
\text { number* }\end{array}$ & $\begin{array}{c}\text { Venous } \\
\text { thrombosis }\end{array}$ & fPS (U/dL) & $\begin{array}{l}\text { tPS } \\
(\mathrm{U} / \mathrm{dL})\end{array}$ & Sequence change $^{\dagger}$ & $\begin{array}{l}\text { Predicted protein } \\
\text { change }^{\ddagger}\end{array}$ & Reference & Comments \\
\hline 1 & $\mathrm{NO}$ & 16 & 123 & - & - & - & \\
\hline 2 & YES & 18 & 63 & 967delTinsGG & Phe323fs & & NOVEL \\
\hline 3 & YES & 18 & 68 & - & - & - & - \\
\hline 4 & YES & 22 & 64 & $(?-133) \_\left({ }^{*} 1 \_?\right) \mathrm{del}$ & Complete deletion & $5,10,11$ & - \\
\hline 5 & YES & 30 & 74 & - & - & - & - \\
\hline 6 & YES & 30 & 58 & $431 \mathrm{C}>\mathrm{A}$ & Thr144Asn & 39 & $\begin{array}{l}\text { Associated with quantitative } \\
\text { deficiency of protein } S\end{array}$ \\
\hline 7 & NO & 31 & 54 & - & - & - & - \\
\hline 8 & NO & 32 & 50 & - & - & - & - \\
\hline 9 & YES & 33 & 78 & - & - & - & - \\
\hline 10 & YES & 33 & 88 & - & - & - & - \\
\hline 11 & NO & 34 & 63 & & & & \\
\hline 12 & NO & 34 & 90 & $* 370 G>A$ & - & - & 3'UTR. NOVEL \\
\hline 13 & NO & 34 & 66 & - & - & - & - \\
\hline 14 & YES & 34 & 53 & - & - & - & - \\
\hline 15 & NO & 34 & 99 & - & - & - & - \\
\hline 16 & YES & 36 & 63 & - & - & - & - \\
\hline 17 & YES & 37 & 66 & $684 C>G$ & Cys228Trp & - & NOVEL \\
\hline 18 & NO & 37 & 57 & - & - & - & - \\
\hline 19 & YES & 38 & 60 & - & - & - & - \\
\hline 20 & NO & 39 & 96 & - & - & - & - \\
\hline 21 & YES & 39 & 81 & - & - & - & - \\
\hline 22 & NO & 39 & 65 & - & - & - & - \\
\hline 23 & YES & 40 & 70 & - & - & - & - \\
\hline 24 & YES & 40 & 58 & - & - & - & - \\
\hline 25 & NO & 40 & 74 & $1301 \mathrm{~T}>\mathrm{C}$ & Val434Ala & & rs6803112 \\
\hline 25 & NO & 40 & 74 & $1501 \mathrm{~T}>\mathrm{G}$ & Ser501Ala & 40 & Protein S Heerlen \\
\hline 26 & YES & 40 & 76 & - & - & - & - \\
\hline 27 & NO & 40 & 81 & - & - & - & - \\
\hline 28 & NO & 40 & 57 & - & - & - & - \\
\hline 29 & NO & 41 & 76 & - & - & - & - \\
\hline 30 & YES & 41 & 61 & - & - & - & - \\
\hline 31 & YES & 41 & 53 & - & - & - & - \\
\hline 32 & NO & 41 & 81 & $1501 \mathrm{~T}>\mathrm{G}$ & Ser501Ala & 40 & Protein S Heerlen \\
\hline 33 & NO & 41 & 82 & - & - & - & - \\
\hline 34 & YES & 42 & 69 & - & - & - & - \\
\hline 35 & YES & 42 & 81 & - & - & - & - \\
\hline 36 & NO & 42 & 59 & - & - & - & - \\
\hline 37 & YES & 42 & 43 & - & - & - & - \\
\hline 38 & NO & 42 & 96 & - & - & - & - \\
\hline 39 & YES & 43 & 74 & - & - & - & - \\
\hline 40 & YES & 43 & 77 & - & - & - & - \\
\hline 41 & NO & 43 & 62 & - & - & - & - \\
\hline 42 & NO & 43 & 132 & - & - & - & - \\
\hline
\end{tabular}




\begin{tabular}{|c|c|c|c|c|c|c|c|}
\hline 43 & NO & 43 & 60 & $698 \mathrm{G}>\mathrm{A}$ & Arg233Lys & $7,41,42$ & $\begin{array}{c}\text { rs41267007 } \\
\text { Probably neutral polymorphism }\end{array}$ \\
\hline 44 & YES & 43 & 60 & $814 G>A$ & Gly272Arg & - & rs41267005 \\
\hline 45 & NO & 44 & 61 & $1095 \mathrm{~T}>\mathrm{G}$ & Asn365Lys & - & NOVEL \\
\hline 46 & NO & 44 & 63 & - & - & - & - \\
\hline 47 & NO & 45 & 88 & - & - & - & - \\
\hline 48 & YES & 45 & 77 & - & - & - & - \\
\hline
\end{tabular}

fPS indicates free protein S; tPS indicates total protein S; MAF indicates minor allele frequency.

${ }^{*}$ Numbers are accordingly to increasing levels of free protein S. ${ }^{\dagger} P R O S 1$ coding DNA reference sequence is NM_000313.3. ${ }^{\ddagger}$ Protein reference sequence is NP_000304.2. 
Figure 1. Risk of venous thrombosis for low free and total protein $S$ levels
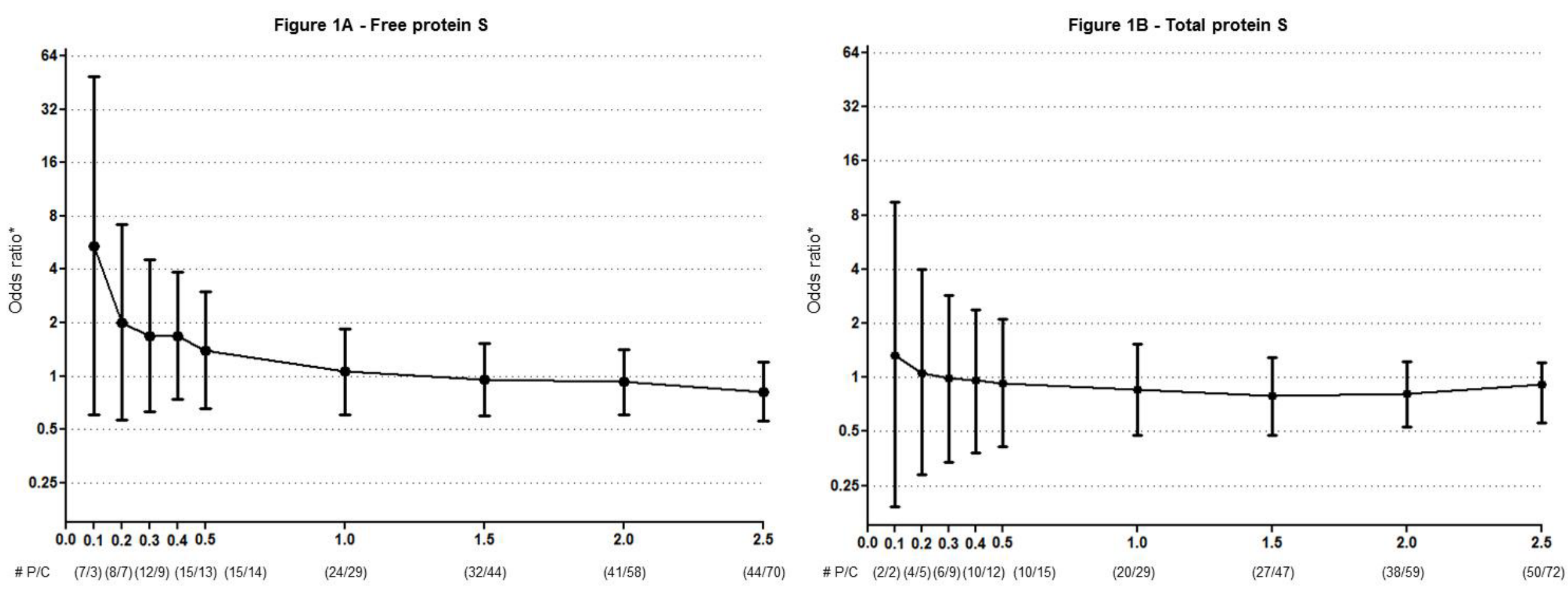

Percentile

Percentile

All odds ratios are compared to free or total protein $S$ levels between 2.5 th- 97.5 th percentile

I denotes $95 \%$ confidence interval.

${ }^{*}$ Adjusted for age and sex.

\# $P$ denotes number of patients and $C$ number of controls per percentile 
Figure 2. Cumulative distribution functions of free and total protein $\mathrm{S}$ levels in patients and controls
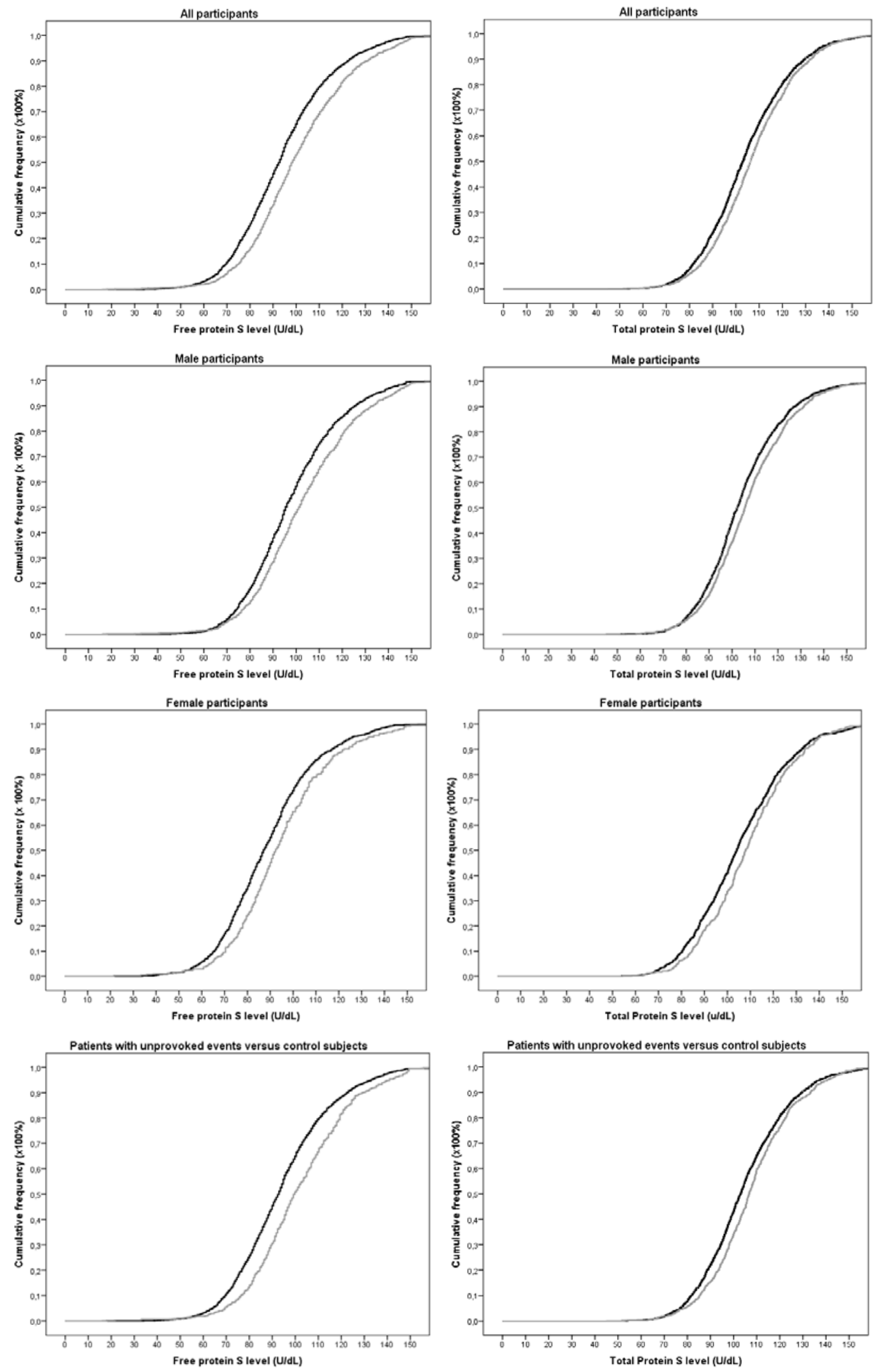

Grey lines indicate patients, black lines controls. 